\title{
Pelatihan Penulisan Karya Ilmiah Bagi Guru-Guru SD Gugus VII Kecamatan Sukasada, Kabupaten Buleleng
}

\author{
I Gede Astawan ${ }^{1 *}$, Ni Wayan Arini' ${ }^{2}$ I Gusti Ngurah Japa ${ }^{3}$
}

1,2,3 Prodi Pendidikan Guru Sekolah Dasar Universitas Pendidikan Ganesha

\section{A R T I C L E I N F O}

Article history:

Received 20 May 2019

Received in revised form

10 June 2019

Accepted 30 July 2019

Available online 30 August 2019

Kata Kunci:

Pelatihan, Penulisan Karya

Ilmiah, Artikel

Keywords:

Training, Scientific Writing, Articles

\begin{abstract}
A B S T R A K
Kegiatan pengabdian pada masyarakat ini dilaksanakan untuk memberikan pengetahuan dan keterampilan guru-guru SD di Gugus VII Kecamatan Sukasada dalam menulis karya ilmiah penyusunan proposal PTK dan artikel ilmiah. Metode yang digunakan dalam kegiatan ini adalah workshop dan pendampingan. Kegiatan melibatkan 21 orang guru sebagai peserta dari gugus VII Kecamatan Sukasada. Hasil dari kegiatan ini menunjukkan bahwa kemampuan guru-guru SD di Gugus VII Kecamatan Sukasada dalam menulis karya ilmiah penyusunan proposal PTK dan artikel ilmiah mengalami peningkatan. Hal ini dapat dilihat dari produk yang dihasilkan, yaitu 5 proposal PTK dan 5 artikel ilmiah.
\end{abstract}

\section{A B S T R A C T}

This community service activity was carried out to provide knowledge and skills to elementary school teachers in Cluster VII of Sukasada Subdistrict in writing scientific work on the preparation of PTK proposals and scientific articles. The method used in this activity is a workshop and mentoring. The activity involved 21 teachers as participants from cluster VII Sukasada District. The results of this activity show that the ability of elementary school teachers in Cluster VII of Sukasada Subdistrict to write scientific papers on the preparation of PTK proposals and scientific articles has increased. This can be seen from the products produced, namely 5 PTK proposals and 5 scientific articles.

\footnotetext{
* Corresponding author.

E-mail addresses: igedeastawan@undiksha.ac.id (I Gede Astawan)
} 


\section{Pendahuluan}

Indonesia, sampai saat ini masih rendah mutu pendidikannya dibandingkan negara-negara maju dan negara-negara berkembang di dunia. Rendahnya mutu pendidikan Indonesia berimplikasi pada rendahnya pula sumber daya manusia (Nilan, 2009). Pemerintah menyadari akan pentingnya pendidikan sebagai salah satu proses dalam pembentukan manusia yang berkualitas dan menjadi bagian penting dalam pembangunan. Sebagai bukti komitmen pemerintah tersebut telah direalisasikan melalui pembenahan pada segenap komponen pendidikan, mulai dari peningkatan anggaran pendidikan sampai pada sarana dan prasarana pendidikan. Peningkatan anggaran pendidikan diimplementasi-kan dalam program dana Bantuan Operasional Sekolah (BOS) yang bertujuan untuk memperbaiki kualitas pembelajaran (Kemendiknas, 2010). Pemerintah juga telah berupaya mengadakan penyempurnaan dalam bidang kurikulum, yaitu dari Kurikulum Kurikulum Tingkat Satuan Pendidikan (KTSP) menjadi Kurikulum 2013. Kurikulum 2013 diimplementasikan untuk memberdayakan potensi peserta didik yang memiliki keterampilan saintifik (Kemdikbud, 2013). Dengan upaya-upaya dan komitmen yang dilakukan oleh pemerintah tersebut, seyogyanya tujuan pemerintah untuk meningkatkan mutu pendidikan di Indonesia dapat tercapai secara optimal.

Namun, hasil-hasil studi menunjukkan kualitas pendidikan di Indonesia masih sangat rendah. Mutu pendidikan di Indonesia berada di peringkat 10 dari 14 negara berkembang di kawasan Asia-Pasifik. Peringkat ini dilansir dari laporan monitoring global yang dikeluarkan lembaga PBB, UNESCO (Muhliz, 2009). Penelitian terhadap kualitas pendidikan dasar ini dilakukan oleh Asian South Pacific Beurau of Adult Education (ASPBAE) dan Global Campaign for Education. Studi dilakukan di 14 negara pada bulan Maret-Juni 2005. Konsorsium Internasional (2010), melaporkan bahwa dalam bidang IPA, Indonesia masuk peringkat 32 dari 36 negara. Fakta-fakta tersebut memberikan gambaran bahwa kualitas pendidikan Indonesia perlu ditingkatkan. Human Development Index (HDI) Indonesia pada tahun 2012 dan 2013 berada di peringkat 108 dari 187 negara (UNDP, 2014: 22; Newsdetik.com, 2014: 1). Sedangkan pada tahun 2014, Indonesia menempati posisi 110 dari 187 negara (National Geographic, 2016: 1). Indeks pembangunan pendidikan untuk semua (education for all) menurut UNESCO dalam EFA Global Monitoring Refort 2011, melaporkan bahwa Indonesia menempati urutan 67 dari 127 negara (Kompas, 2011: 6).

Bercermin dari rendahnya kualitas pendidikan di Indonesia, sudah tentu ada permasalahan yang mesti dibenahi. Salah satunya adalah persoalan mutu guru. Guru merupakan ujung tombak di dalam meningkatkan kualitas pendidikan. Kurikulum yang bagus, sarana dan prasarana yang memadai belum menjadi jaminan dalam meningkatkan kualitas pendidikan tanpa didukung oleh guru yang berkualitas (Muhliz, 2009). Oleh karena itu, peningkatan kualitas guru merupakan suatu keharusan.

Sebagai salah satu upaya meningkatkan kualitas guru adalah melalui kegiatan pengembangan profesi. Pengembangan profesi guru merupakan kegiatan yang dilakukan guru dalam rangka pengamalan ilmu pengetahuan, teknologi, dan keterampilan untuk meningkatkan mutu, baik dalam proses pembelajaran, menghasilkan sesuatu yang bermanfaat bagi dunia pendidikan/masyarakat, maupun peningkatan profesionalisme guru (Suarni, 2009). Oleh karena itu, peningkatan profesi guru harus bertumpu pada paradigma pengembangan dan peningkatan kualitas guru.

Dengan diberlakukannya Undang-Undang Nomor 14 tahun 2005 tentang Guru dan Dosen memberikan konsekuensi logis bagi para guru dan dosen untuk memenuhi beberapa hal yang diundangkan tersebut. Di antaranya, guru/dosen harus meningkatkan dan mengembangkan profesi sebagai pendidik. Peningkatan profesionalisme guru dapat ditempuh dengan cara mengikuti sertifikasi guru, dan kenaikan pangkat ke golongan yang lebih tinggi. Dari dua kegiatan tersebut, tampak belum mendapat respon sesuai dengan harapan pemerintah. Kenyataan tersebut dapat dilihat berdasarkan sertifikasi guru yang dilaksanakan melalui penilaian portofolio guru, masih banyak guru tidak lulus sertifikasi (Suarni, 2009). Ini membuktikan bahwa ketidaksiapan para guru menyongsong perubahan paradigma tuntutan peningkatan profesionalisme guru. Terlebih lagi fakta yang cukup mengagetkan ditemukan bahwa hanya sebagian kecil guru yang mampu menduduki golongan IVb di Bali (Diknas Propinsi Bali). Dengan kata lain, guru-guru hanya mampu menduduki golongan IVa. Hal ini dapat dicapai karena kenaikan golongan sampai IVa hanya diperoleh melalui angka kredit yang belum mensyaratkan karya tulis ilmiah (KTI).

Wardani, dkk. (2007; Arini \& Astawan, 2014) mendefinisikan karya ilmiah adalah suatu karangan yang disusun secara sistematis dan bersifat ilmiah. Sistematis berarti bahwa karangan atau karya tulis tersebut disusun menurut aturan tertentu sehingga kaitan antara bagian-bagian tersebut sangat jelas dan padu. Bersifat ilmiah berarti bahwa karya tulis tersebut menyajikan satu deskripsi, gagasan, argumentasi atau pemecahan masalah yang didasarkan pada berbagai bukti empirik atau kajian teoretik sehingga pembaca dapat merunut atau mencari kebenaran bukti empirik atau teori yang mendukung gagasan tersebut. 
Sejak tahun 2004, diterapkan kebijakan bahwa peningkatan profesionalisme guru melalui kenaikan pangkat ke golongan IVb dengan mempersyaratkan agar guru memiliki KTI dengan nilai Cum 12 poin. Persyaratan adanya KTI ini menjadi kendala bagi guru untuk naik pangkat ke golongan IVb. Terlebih lagi, kini dengan adanya peraturan baru yang dikeluarkan oleh Menteri Pendayagunaan Aparatur Negara dan Reformasi Birokrasi dalam bentuk PermenPANRB No. 16 tahun 2009 tentang kenaikan pangkat guru (termasuk kepala sekolah), yang telah diberlakukan sejak tahun 2011, menjadi tantangan tersendiri bagi guru-guru dan kepala sekolah. Adapun aturan baru tentang kenaikan pangkat bagi guru yang dimaksud adalah sebagai berikut (Sulipan, 2010). (1) Kenaikan pangkat dari IIIa ke IIIb wajib melaksanakan pengembangan diri (pelatihan dan kegiatan kolektif guru) yang besarnya 3 angka kredit. (2) Kenaikan pangkat dari IIIb ke IIIc wajib melaksanakan pengembangan diri (pelatihan dan kegiatan kolektif guru) yang besarnya 3 angka kredit dan publikasi ilmiah/karya inovatif (karya tulis ilmiah, membuat alat peraga, alat pelajaran, karya teknologi/seni) dengan 4 angka kredit. (3) Kenaikan pangkat dari IIIc ke IIId wajib melaksanakan pengembangan diri (pelatihan dan kegiatan kolektif guru) yang besarnya 3 angka kredit dan publikasi ilmiah/karya inovatif (karya tulis ilmiah, membuat alat peraga, alat pelajaran, karya teknologi/seni) dengan 6 angka kredit. (4) Kenaikan pangkat dari IIId ke IVa wajib melaksanakan pengembangan diri (pelatihan dan kegiatan kolektif guru) yang besarnya 4 angka kredit dan publikasi ilmiah/karya inovatif (karya tulis ilmiah, membuat alat peraga, alat pelajaran, karya teknologi/seni) dengan 8 angka kredit. (5) Kenaikan pangkat dari IVa ke IVb wajib melaksanakan pengembangan diri (pelatihan dan kegiatan kolektif guru) yang besarnya 4 angka kredit dan publikasi ilmiah/karya inovatif (karya tulis ilmiah, membuat alat peraga, alat pelajaran, karya teknologi/seni) dengan 12 angka kredit. (6) Kenaikan pangkat dari IVb ke IVc wajib melaksanakan pengembangan diri (pelatihan dan kegiatan kolektif guru) yang besarnya 4 angka kredit dan publikasi ilmiah/karya inovatif (karya tulis ilmiah, membuat alat peraga, alat pelajaran, karya teknologi/seni) dengan 12 angka kredit (dan harus presentasi di depan tim penilai). (7) Kenaikan pangkat dari IVc ke IVd wajib melaksanakan pengembangan diri (pelatihan dan kegiatan kolektif guru) yang besarnya 5 angka kredit dan publikasi ilmiah/karya inovatif (karya tulis ilmiah, membuat alat peraga, alat pelajaran, karya teknologi/seni) dengan 14 angka kredit. (8) Kenaikan pangkat dari IVc ke IVd wajib melaksanakan pengembangan diri (pelatihan dan kegiatan kolektif guru) yang besarnya 5 angka kredit dan publikasi ilmiah/karya inovatif (karya tulis ilmiah, membuat alat peraga, alat pelajaran, karya teknologi/seni) dengan 20 angka kredit.

Berdasarkan PermenPANRB No. 16 tahun 2009 di atas, tampak bahwa kenaikan pangkat mulai dari IIIb ke IIIc dan seterusnya, semua mensyaratkan pengembangan diri dan publikasi ilmiah/karya inovatif yang salah satunya adalah berupa KTI. Oleh karena itu, mau tidak mau, suka tidak suka, jika seorang guru ingin naik pangkat, maka harus mampu menghasilkan karya ilmiah.

Berkaitan dengan aturan kenaikan pangkat tersebut, apabila hal ini tidak diantisipasi sejak dini, dikawatirkan ke depannya guru-guru hanya mampu menduduki golongan IIIb. Untuk itu, penting dilakukan langkah antisipatif berupa kegiatan workshop penyusunan KTI bagi guru-guru. Melalui kegiatan workshop penulisan KTI diharapkan nantinya dapat menyiapkan guru-guru dalam memenuhi aturan kenaikan pangkat sesuai dengan PermenPANRB No. 16 tahun 2009 tentang kenaikan pangkat guru.

\section{Metode}

Dalam upaya mengatasi kesulitan yang dialami mitra, yakni Kelompok Kerja Guru (KKG)

Kecamatan Buleleng, solusi yang ditawarkan adalah dengan menerapkan suatu metode yang inovatif dan kreatif untuk meningkatkan kompetensi guru dalam menulis. Metode inovatif dan kreatif yang diterapkan yaitu penggunaan metode peta pikiran.

Kegiatan pertama dimulai dengan melakukan identifikasi masalah. Setelah masalah teridentifikasi, selanjutnya dirumuskan solusi pemecahannya. Dalam kegiatan pengabdian masyarakat ini solusinya melalui workshop dan pendampingan. Kegiatan diawali dengan penyajian materi berkaitan dengan metode peta pikiran. Workshop dirancang dalam waktu 3 (tiga hari). Melalui workshop tersebut, guruguru diberikan pembekalan bagaimana menerapkan metode peta pikiran sehingga dapat membantu memudahkan dalam menulis. Setelah guru memahami penggunaan metode peta pikiran, kegiatan selanjutnya memulai menyusun PTK dan menulis artikel ilmiah. Setelah melakukan rangkaian kegiatan workshop, untuk memastikan produk yang dihasilkan, maka dilanjutnya dengan proses pendampingan. Pendampingan dilaksanakan melalui bimbingan face to face secara berkelanjutan sampai dihasilkan produk berupa proposal PTK dan artikel ilmiah selama dua bulan.

Berdasarkan kerangka pemecahan masalah di atas, adapun metode pelaksanaan kegiatan pengabdian pada masyarakat ini adalah menggunakan metode workshop (pelatihan) dan pendampingan. 
Secara lebih rinci langkah-langkah pelaksanaan program adalah sebagai berikut. (1) workshop pembuatan proposal PTK dan penulisan artikel, dan 2) pendampingan pembuatan proposal PTK dan artikel ilmiah.

Khalayak sasaran utama dalam kegiatan ini adalah guru-guru SD di Gugus VII Kecamatan Sukasada. Guru-guru yang dilibatkan adalah perwakilan dari masing-masing sekolah yang ada di Gugus VII Kecamatan Sukasada, yaitu sebanyak 21 Orang. Dipilihnya guru-guru SD sebagai mitra dalam melakukan program pengabdian pada masyarakat ini, karena sampai saat ini, guru-guru SD termasuk guru-guru SD di Gugus VII Kecamatan Sukasada mengalami kesulitan untuk naik pangkat yang mempersyaratkan harus memiliki publikasi karya ilmiah.

\section{Hasil dan pembahasan}

Sejalan dengan tujuan kegiatan ini, yaitu melatih guru-guru SD Gugus VII Kecamatan Sukada, Kabupaten Buleleng untuk mampu menyusun proposal PTK dan menulis artikel ilmiah, maka gambaran dan hasil pelaksanaan kegiatan pengabdian kepada masyarakat ini dapat dipaparkan sebagai berikut. Kegiatan dilaksanakan di Gugus VII, yaitu di SD 5 Selat. Dipilihnya tempat tersebut, karena SD 5 Selat paling strategis di antara 6 sekolah yang ada di Gugus VII Kecamatan Sukasada untuk melaksanakan kegiatan. Sekolah ini mudah dijangkau dari sekolah-sekolah lainnya.

Kegiatan diikuti oleh 21 guru yang berasal dari 6 sekolah di gugus VII Kecamatan Sukasada. Sebelum kegiatan dimulai, terlebih dahulu dilakukan registrasi dan pembagian snack. Kegiatan dimulai dengan penyajian materi oleh narasumber I dan narasumber II. Narasumber I membawakan materi tentang penyusunan proposal PTK dan Narasumber II membawakan materi tentang penyusunan artikel ilmiah. Setelah masing-masing narasumber selesai menyajikan, dilanjutkan dengan tanya jawab. Setelah selesai tanya jawab, peserta dipersilakan istirahat menikmati kudapan (makan siang), sebelum dilanjutkan ke acara berikutnya.

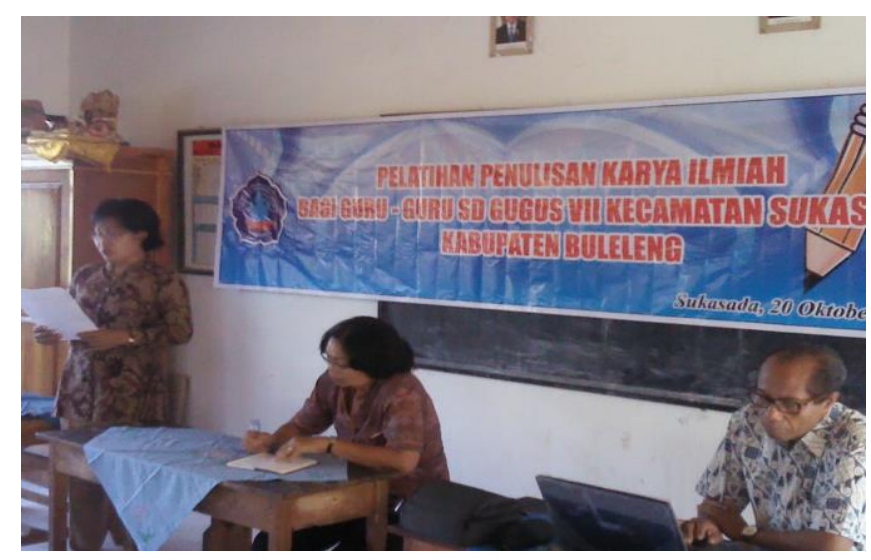

Gambar 1. Penyajian Materi

Setelah selesai istirahat, acara dilanjutkan dengan sesi pelatihan penyusunan draf proposal PTK dan draf artikel ilmiah. Pada kegiatan ini baru mampu menghasilkan draf proposal dan draf artikel ilmiah, belum hasil final. Setelah selesai menyusun draf proposal PTK dan draf artikel hanya ditutup. Kemudian, sesuai kesepakatan draf tersebut dilanjutkan dikerjakan di rumah masing-masing. Setelah draf diselesaikan, dilakukan pendampingan di SD 5 Selat untuk menyempurnakan produk yang dihasilkan menjadi produk final. Produk yang dihasilkan yaitu proposal PTK dan artikel ilmiah. 


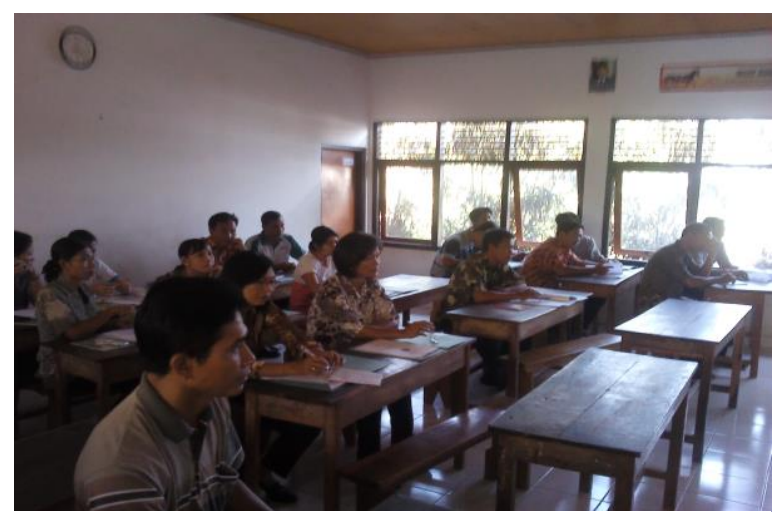

Gambar 2. Peserta Pelatihan

Keberhasilan program ini karena para peserta antusias mengikuti kegiatan-kegiatan yang dilaksanakan. Peserta menyatakan senang mengikuti pelatihan karena mereka merasa mendapatkan manfaat dari program pengabdian ini. Guru-guru yang mengikuti pelatihan merasa dibantu untuk meningkatkan profesionalisme mereka. Guru-guru terbantu untuk memenuhi persyaratan kenaikan pangkat dan golongan berkaitan dengan pemenuhan karya ilmiah.

Keberhasilan kegiatan ini sejalan dengan kajian teori dan bukti empiris sebelumnya berkaitan dengan metode peta pikiran (Deporter, et al., 2001; Hernowo, 2005; Buzan dan Barry, 2004). Deporter, et al. (2001) dan Hernowo (2005), membuktikan bahwa metode peta pikiran dapat membantu seseorang menumbuhkan pemahaman dan ingatan serta menumbuhkan daya kreativitas, sehingga dapat tercipta pembelajaran menulis yang menarik dan menyenangkan. Hal senada juga ditemukan oleh Buzan \& Barry (2004), mengungkapkan bahwa peta pikiran dapat membantu seseorang dalam menyusun informasi dan melancarkan aliran pikiran.

Menyimak antusiasme peserta pelatihan, tampaknya keberlajutan kegiatan ini optimis dapat dilaksanakan. Sebagai tindak lanjut kegiatan ini adalah guru-guru yang telah berhasil menyusun proposal PTK bisa meneruskan melakukan penelitian ke lapangan. Selanjutnya dilakukan analisis data, dan dibuatkan laporannya. Dengan demikian, laporan tersebut dapat dimanfaatkan untuk kenaikan pangkat mereka. Di samping itu, laporan tersebut dapat dibuatkan artikel ilmiahnya untuk selanjutnya dikirimkan kejurnal ilmiah. Artikel ilmiah yang berhasil dimuat di jurnal ilmiah juga dapat dimanfaatkan sebagai persyaratan kenaikan pangkat.

\section{Simpulan dan saran}

Berdasarkan kegiatan yang telah dilakukan dan indikator keberhasilan yang telah ditetapkan, dapat disimpulkan hal-hal sebagai berikut. (1) Kemampuan guru-guru SD di Gugus VII Kecamatan Sukasada dalam menulis karya ilmiah penyusunan proposal PTK mengalami peningkatan. Hal ini dapat dilihat dari produk yang dihasilkan, di mana guru-guru telah mampu menghasilkan proposal penelitian tindakan kelas. (2) Kemampuan guru-guru SD di Gugus VII Kecamatan Sukasada dalam menulis karya ilmiah penyusunan artikel mengalami peningkatan. Hal ini dapat dilihat dari produk yang dihasilkan, di mana guru-guru telah mampu menghasilkan artikel ilmiah.

Berdasarkan kegiatan yang telah dilakukan dapat disarankan hal-hal sebagai berikut. (1) Guru-guru peserta pelatihan diharapkan menindaklanjuti secara mandiri proposal PTK yang telah dibuat untuk dilakukan penelitian. Penelitian tersebut selanjutnya dilaporkan kepada pihak yang berwenang, dalam hal ini dinas pendidikan setempat. Selain berupa laporan, agar dibuat pula artikel hasil penelitiannya. (2) Pihak sekolah diharapkan terus menyebarluaskan kepada guru-guru lainnya yang tidak berkesempatan mengikuti kegiatan pelatihan, agar termotivasi menulis karya ilmiah. Di samping itu, memberikan kesempatan lebih banyak lagi kepada guru-guru untuk mengikuti kegiatan pelatihan yang sejenis dalam rangka meningkatkan profesionalisme guru. (3) Kepada pengambil kebijakan/pemerintah, diharapkan merancang kegiatan yang sejenis, yaitu melaksanakan pelatihan penulisan karya ilmiah dan atau menyediakan dana untuk kegiatan tersebut. Dengan demikian, guru-guru yang belum dapat kesempatan dalam pelatihan ini, bisa mengikuti pelatihan dikesempatan lain.

\section{Daftar Rujukan}

Arini, Ni W. \& Astawan, I G. (2014). Penulisan Karya Ilmiah Dilengkapi Dengan Teknik Menulis Esai. Singaraja: Undiksha Press. 
Buzan, T. \& Barry. (2004). Memahami Peta Pikiran. Edisi Milenium. Batam: Interaksara.

DePorter, B., Reardon, M., \& Nourie, S.S. (2004). Quantum Teaching. Bandung: Kaifa.

Hernowo. (2005). Quantum Writing. Bandung: Mizan Learning Center.

Kemendiknas. (2010). Buku Panduan Bantuan Oprasional Sekolah Untuk Pendidikan Gratis dalam Rangka Wajib Belajar Sembilan Tahun Yang Bermutu. Jakarta: Kemendiknas.

Kemendikbud. (2013). Kompetensi dasar SD/MI. Jakarta: Kementerian Pendidikan dan Kebudayaan.

Konsorsium Indonesia. (2010). Pendidikan IPA. tersedia pada http://pendidikan-IPA.blogspot.com/20080901 archive.html. Diunduh tanggal 1 Septem-ber 2010.

Kompas. (2011). Indonesia, indek pendidikan pembangunan untuk semua. Selasa, 25 Oktober 2011.

Muhliz. (2009). Mutu Pendidikan. Tersedia pada http://t4belajar.word-press.com/2009/04/24/pendidikan-indonesia-ranking-109-malaysia-61/. Diunduh tanggal 1 September 2010.

National Geographic.ci.id. (2016). UNDP: Indeks pembangunan manusia indonesia alami kemajuan. Tersedia pada: http://nationalgeo-graphic.co.id/berita/2016/01/undp-indeks-pembangunanmanusia-indonesia-alami-kemajuan, diakses pada tanggal 9 Desember 2016.

Nilan, P. (2009). Indonesia: New directions in educational research. Jurnal Ilmiah Pendidikan dan Pembelajaran, 6 (2), 1141-1296.

News.detik.com. (2014). Posisi indeks pembangunan manusia indonesia: Rangking 108 dari 187 negara. Tersedia pada: http://news.detik.com/be-rita/2647298/posisi-indeks-pembangunan-manusiaindonesia-rangking-108-dari-187-negara, diakses tanggal 11 Nopember 2016.

Nilan, P. (2009). Indonesia: New Directions in Educational Research. Jurnal Ilmiah Pendidikan dan Pembelajaran. Vol. 6. No. 2. Hal. 1141-1296.

PermenPANRB Nomor 16 tahun 2009 Tentang Kenaikan Pangkat Guru.

Suarni, Ni K. (2009). Pelatihan Penyusunan Karya Tulis Ilmiah (KTI) Sebagai Upaya untuk Mendukung Peningkatan Jabatan Fungsional Guru pada Para Guru di Kabupaten Buleleng. Laporan P2M. Universitas Pendidikan Ganesha.

Sulipan. (2010). Aturan Baru untuk Kenaikan Pangkat/Jabatan bagi Guru. Tersedia pada http://sulipan.wordpress.com/2010/01/01/aturan-baru-untuk-kenai-kan-pangkatjabatan-bagiguru. Diunduh tanggal 7 April 2011.

UNDP. (2014). Human development index 2014. Tersedia pada: http://fe.gunadarma.ac.id/majalah/2014/12/30/human-development-index-2014/__diakses tanggal 11 Nopember 2016.

Undang-undang Republik Indonesia Nomor 14 Tahun 2005 tentang guru dan dosen.

Wardani, dkk. (2007). Teknik Penulisan Karya Ilmiah. Jakarta: Universitas Terbuka. 